\title{
PENGOLAHAN DAN PENINGKATAN KADAR PROTEIN FISH NUGGET BERBAHAN DASAR LIMBAH IKAN DENGAN PEMBERIAN EKSTRAK KULIT NANAS
}

\author{
Muhammad Rijal \\ Program Studi Pendidikan Biologi, IAIN Ambon \\ ${ }^{1}$ E-mail: rijal_rijal82@yahoo.co.id
}

\begin{abstract}
Abstrak: Fish nugget berbahan limbah ikan merupakan salah satu solusi yang tepat untuk mengatasi permasalahan pencemaran lingkungan oleh produksi limbah kulit ataupun kepala ikan di Propinsi Maluku. Hasil penelitian menunjukkan bahwa terjadi peningkatan kadar protein pada fish nugget berbahan limbah ikan dengan menggunakan ekstrak kulit nanas sebagai sumber enzim. Peningkatan kandungan protein pada fish nugget disebabkan oleh aktivitas protease yang terdapat pada ekstrak kulit nanas yang mampu menyederhanakan polipeptida menjadi monomer yang lebih sederhana sehingga lebih mudah dicerna oleh saluran pencernaan.
\end{abstract}

\section{Kata Kunci: Fish Nugget, Kadar Protein, Bromelin}

\section{PROCESSING AND ELEVATED LEVELS OF PROTEIN FISH BASED NUGGETS WASTE FISH WITH EXTRACT PINEAPPLE THE SKIN}

\begin{abstract}
Fish nuggets made waste fish is one of the best solution to solve the problem environmental pollution by the production of waste the skin or the head of in the province of Maluku. The research results show that there are elevated levels of a protein on fish nuggets made waste fish with use extract the skin pineapple as a source of an enzyme. An increase in the womb a protein on fish nuggets caused by activity protease that is added to extract the skin pineapple able to do simplicity polypeptide be monomers simpler so it is cheaper digested by the digestive tract.
\end{abstract}

\section{Keywords: Fish Nugget, levels Of Protein, Bromelain}

Industri perikanan di Indonesia cukup banyak jumlahnya dan terkonsentrasi pada beberapa lokasi khusus seperti Propinsi Maluku, tepatnya di Asilulu. Hanya saja penelitian limbah cair dari sentra-sentra Industri Pengolahan perikanan tersebut belum pernah ada, walaupun keluhan masyarakat yang bermukim disekitarnya sudah mulai terdengar terutama komplain terhadap bau yang ditimbulkannya. Limbah pada dasarnya adalah suatu bahan yang terbuang atau dibuang dari suatu sumber aktifitas manusia, 
maupun proses alam dan tidak atau belum mempunyai nilai ekonomi, bahkan dapat mempunyai nilai ekonomi negatif karena penanganan untuk membuang atau membersihkan memerlukan biaya yang cukup besar disamping dapat mencemari lingkungan (Burgess, G.H.O., C.L. Cutting, J.A. Lovern dan J.J. Waterman. 1965).

Limbah merupakan masalah di dalam usaha suatu industri termasuk industri perikanan yang menghasilkan limbah pada proses penangkapan ikan, penanganan, pengangkutan, distribusi dan pemasaran. Limbah perikanan dapat dapat berupa ikan yang terbuang, tercecer, dan sisa olahan yang menghasilkan cairan dan pemotongan, pencucian dan pengolahan produk.Dampak limbah industri pengolahan ikan terhadap kesehatan lingkungan dapat dirasakan dengan bau limbah ikan yang menyengat sehingga mencemari udara, dapat dihinggapi lalat yang dapat menimbulkan penyakit dan berbagai dampak negatif lainnya.Industri pengolahan ikan harus memiliki metode dalam pengolahan limbah olahan ikan sehingga limbah olahan ikan tidak hanya dibuang begitu saja ditempat pembuang sampah.Bila industri pengolahan limbah tidak memperhatikan hal ini maka dapat menjadi tempat pertumbuhan bakteri dan virus yang dapat menyebabkan penyakit.

Proses pengolahan ikan dengan hanya memanfaatkan daging mengakibatkan banyaknya limbah ikan yang dihasilkan dan limbah tersebut tidak semuanya dikelolah dengan baik oleh masyarakat setempat. Limbah ikan yang meliputi kepala, tulang, dan jeroan memiliki kandungan gizi yang cukup tinggi, seperti jeroan dan kepala ikan masih banyak mengandung protein dan omega 6 serta omega 9, sedangkan bagian tulang banyak mengandung calcium yang sangat baik diolah menjadi pakan ternak. Di dalam kulit nanas terkandung bromelin yang merupakan protease dengan kemampuan memecah molekul protein menjadi uni asam amino. Mekanisme kerja protease pada kulit nanas adalah memutuskan ikatan peptida pada rantai polipeptida sehingga akan terurai menjadi monomer-monomer sederhana. Monomer sederhana dari protein adalah aam amino yang merupakan biomolekul yang dibutuhkan oleh tubuh sebagai unit structural di dalam penyusunan sel, jaringan, dan organ.

Penambahan protease yang diisolasi dari kulit nanas akan memudahkan alat-alat pencernaan dalam melakukan proses pencernaan pada produk olahan limbah ikan. Selain mengandung protease, pemberian ekstrak kulit nanas mampu menurunkan $\mathrm{pH}$ adonan olahan limbah ikan, sehingga berperan dalam menghambat pertumbuhan mikroba yang tidak bisa tumbuh pada kondisi lingkungan yang asam. Oleh karena itu, adanya penelitian ini, diharapkan dapat memberikan pengetahuan dan informasi kepada masyarakat yang di wilayahnya terdapat industri pengolahan ikan tentang cara mengolah limbah ikan dengan menambahkan ekstrak limbah kulit nanas menjadi aneka produk makanan dengan nilai gizi dan ekonomi tinggi serta aman untuk dikonsumsi. 


\section{METODE PENELITIAN}

Jenis penelitian ini adalah eksperimen laboratorium yang bertujuan untuk mengetahui cara pengolahan limbah ikan menjadi fish nugget, menganalisis kandungan protein fish nugget berbahan dasar limbah ikan yang diproduksi dengan menggunakan ekstrak kulit nanas. Penelitian ini dilaksanakan selama 2 bulan yang terhitung mulai bulan juni-juli 2016 yang berlokasi di 3 tempat yaitu: pengambilan limbah ikan di Asilulu Maluku Tengah sedangkan pembuatan fish nuggt dan pengujian kadar protein dilakukan di laboratorium MIPA IAIN Ambon.

Variabel dalam penelitian ini adalah konsetrasi ekstrak kasar kulit nanas yang terdiri dari 4 perlakuan $(100 \%, 80 \%, 60 \%$, dan $40 \%)$, sedangkan yang menjadi variabel terikat adalah kadar protein ( $\mathrm{N}$ total) pada fish nugget. Rancangan yang digunakan dalam penelitian ini adalah "rancangan acak lengkap" dengan satu faktor yaitu konsetrasi ekstrak kasar kulit nanas dengan jumlah 3 ulangan sehingga total pengamatan dalam penelitian ini adalah 9 unit. Obyek dalam penelitian ini adalah peningkatan kadar protein fish nugget berbahan dasar limbah ikan dengan menggunakan ekstrak kulit nanas sebagai sumber protease.

\section{Isolasi Bromelin}

Enzim yang diisolasi adalah jenis bromelin (protease) yang berfungsi memecah protein menjadi asam amino sehingga mampu meningkatkan nilai cerna makanan. Bromelin yang diekstraksi dari limbah kulit nanas diperoleh dengan cara menimbang 100 g limbah kulit nanas yang sudah matang dan ditambahkan dengan $100 \mathrm{ml}$ air steril. Campuran limbah kulit nanas dengan air selanjutnya diblender sampai halus dan melakukan penyaringan untuk memisahkan antara cairan dengan ampas.Cairan yang diperoleh selanjutnya dicentrifugasi selama 20 menit dengan kecepatan $2000 \mathrm{rpm}$ atau bisa didiamkan selama 24 jam.Setelah terpisah antara ampas sisa dengan cairan bening ekstrak, maka diperoleh sediaan enzim bromelin kasar yang nantinya bisa dijadikan sebagai bahan tambahan dalam pengolahan limbah ikan menjadi fish nugget. Sediaan ekstrak yang diperoleh diasumsikan sebagai konsetrasi enzim 100\% dan selanjutnya diencerkan dengan menggunakan rumus pengenceran $(\mathrm{M} 1 . \mathrm{V} 1=\mathrm{M} 2 . \mathrm{V} 2)$ untuk mendapatkan variasi konsetrasi yang diinginkan. Konsetrasi enzim yang digunakan dalam penelitian ini adalah 100\%, 80\%, 60\%, dan 40\% (100 ml ekstrak/1 kg limbah ikan yang sudah dihaluskan).

\section{Pengolahan Limbah Ikan Menjadi Fish Nugget}

Limbah ikan berupa jeroan, kulit, dan daging kepala ikan yang telah direndam dengan ekstrak kulit nanas dibiarkan selama 20 menit lalu diblender sampai halus. Setelah halus, dicampurkan dengan bahan-bahan berupa bawang putih (4 siung), bawang merah (4 siung), merica (5 g), lengkuas (10 g), roti tawar (3 lembar), tepung kanji (200 g), telur 3 butir, dan penyedap rasa (1 bks) lalu dihomogenkan. Adonan yang terbentuk selanjutnya dimasukan ke dalam Loyang berukuran $30 \mathrm{~cm}$ x $10 \mathrm{~cm}$ ) lalu dikukus selama 
20 menit.Setelah matang, selanjutnya dilakukan pemotongan dengan bentuk dadu ukuran $3 \mathrm{~cm}$ dan dicelupkan pada kocokan telur dan ditaburi dengan tepung roti (fish nugget sudah siap untuk diolah atau disimpan dalam freezer).

\section{Pengujian Kadar Protein Fish Nugget}

Untuk menguji kandungan protein pada setiap perlakuan dilakukan dengan menggunakan spektrofotmetri pada panjang gelombang $260 \mathrm{~nm}$. Sampel fish nugget ditimbang sebanyak $10 \mathrm{~g}$ dan dioven selama 24 jam pada suhu $60{ }^{\circ} \mathrm{C}$. Setelah sampel fish nugget kering selanjutnya dihaluskan dan ditambahkan dengan aquadest sebanyak 100 $\mathrm{ml}$ lalu disaring dengan menggunakan kertas saring. Filtrat yang tertampung pada labu takar dicukupkan volumenya sampai $100 \mathrm{ml}$. menambahkan biuret $5 \mathrm{ml}$ pada $5 \mathrm{ml}$ sampel uji (diambil dari hasil filtrat). Jika hasil pemberian biuret menunjukan warna ungu, maka sampel yang akan diuji positif mengandung protein. Untuk pengujian kadar protein, maka dibuat larutan standar berupa bovin serum albumin (0 ppm, 1 ppm, 2 ppm, 3 ppm, 4 ppm, dan 5 ppm) dan ditambah dengan biuret dan dibuat kurva standar untuk protein sebagai dasar dalam penentuan kadar protein sampel. Blanko dalam pengukuran kadar protein adalah biuret.

\section{HASIL DAN PEMBAHASAN \\ Pembuatan Fish Nugget}

Pembuatan fish nugget sudah sering dilakukan di Indonesia, tetapi bahan yang digunakan adalah daging ikan tenggiri. Penelitian ini mencoba menggunakan limbah ikan seperti jeroan, kulit ikan, dan daging pada kepala ikan serta bantuan protease yang diekstrak dari kulit nanas dengan tujuan untuk meningkatkan nilai cerna fish nugget.Limbah ikan berupa kulit, jeroan, dan kepala ikan dicuci bersih dengan air mengalir yang bertujuan untuk menghilangkan kotoran ataupun sisa darah yang melekat pada organ ikan ikan.Memisahkan bagian limbah berdasarkan jenisnya dan melakukan tahap penghalusan dengan menggunakan blender.Menyiapkan ekstrak kulit nanas sesuai dengan konsetrasi yang ditentukan $(100 \%, 80 \%, 60 \%$, dan $40 \%)$ yang digunakan untuk merendam limbah ikan yang telah dihaluskan.Merendam limbah ikan yang telah dihaluskan ke dalam larutan kulit nanas selama 30 menit kemudian limbah ikan siap untuk diolah menjadi fish nugget.

Menimbang $1000 \mathrm{~g}$ limbah ikan kemudian menambahkan dengan 3 lembar roti tawar. Haluskan ikan, roti tawar dengan bumbu seperti: (4 siung), bawang merah (4 siung), merica (5 g), lengkuas ( $10 \mathrm{~g})$. Setelah adonan halus ditambahkan dengan penyedap rasa dan $200 \mathrm{~g}$ tepung kanji serta 3 butir telur ayam ras.Adonan siap untuk dikukus selama 30 menit dan setelah matang dilakukan pemotongan sesuai selera.Fish nugget direndam di dalam kocokan telur lalu diguling ke dalam tepung panir untuk selanjutnya siap untuk digoreng. 


\section{Analisis Kandungan Protein (N-Total) Fish Nugget}

Pada penelitian ini dilakukan inovasi dalam upaya meningkatkan nilai cerna produk olahan limbah ikan dengan melakukan perendaman ekstrak kulit nanas yang merupakan sumber protease dan berfungsi dalam memutuskan ikatan peptide dari protein. Perlakuan dalam penelitian ini adalah dengan memvariasikan konsetrasi ekstrak kulit nanas $(100 \%, 80 \%, 60 \%$, dan $40 \%)$ kemudian melihat pengaruhnya terhadap peningkatan kadar protein (N-total) pada fish nugget, data tentang kadar protein fish nugget setelah perlakuan dapat dilihat pada Tabel 1 berikut

Tabel 1. Kadar Protein Fish Nugget setelah Perlakuan

\begin{tabular}{|c|c|c|c|c|c|}
\hline \multirow{2}{*}{ Perlakuan } & \multicolumn{3}{|c|}{ Ulangan (ppm) } & \multirow{2}{*}{ Jumlah (ppm) } & Rerata (ppm) \\
\cline { 2 - 4 } & 1 & 2 & 3 & & \\
\hline $100 \%$ & 0,023 & 0,025 & 0,023 & 0,071 & 0,024 \\
\hline $80 \%$ & 0,028 & 0,032 & 0,027 & 0,087 & 0,029 \\
\hline $60 \%$ & 0,008 & 0,008 & 0,010 & 0,026 & 0,009 \\
\hline $40 \%$ & 0,430 & 0,470 & 0,431 & 1,331 & 0,444 \\
\hline
\end{tabular}

Berdasarkan tabel 1 tersebut terlihat bahwa pemberian ekstrak kulit nanas degan konsetrasi $40 \%$ memberikan hasil yang lebih baik terhadap kadar protein fish nugget bila dibandingkan dengan konsetrasi 100\%, 80\%, dan 60\%. Peningkatan kadar protein fish nugget pada tiap-tiap perlakuan bervariasi dan tidak mengikuti besarnya konsetrasi ekstrak. Untuk lebih jelasnya dapat dilihat pada Gambar 1 berikut

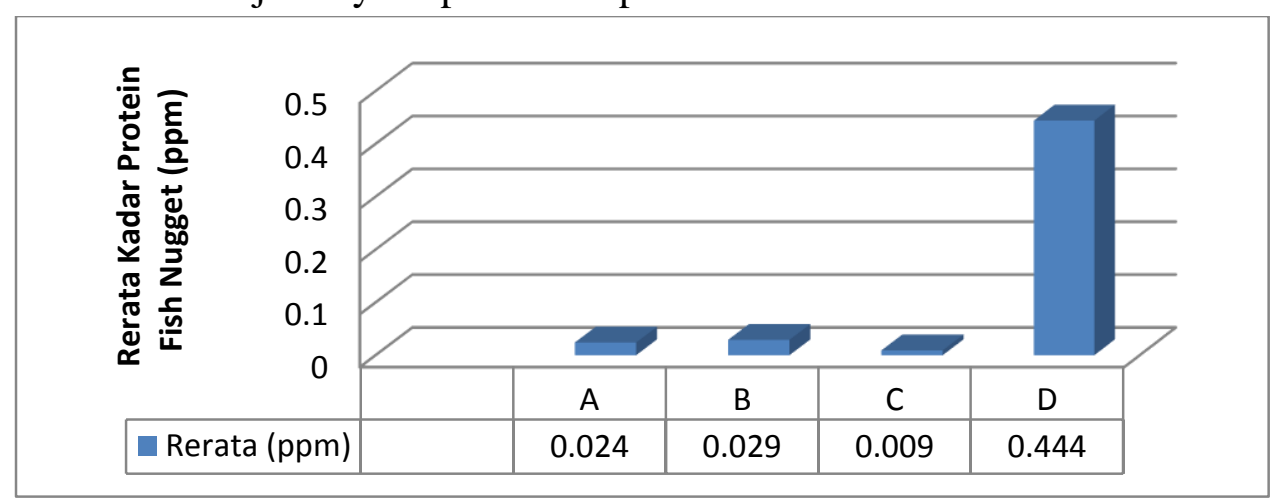

Gambar 1. Rerata Kadar Protein pada Masing-Masing Perlakuan

Gambar 1 tersebut menunjukkan bahwa rerata kadar protein pada perlakuan A (100\% ekstrak kulit nanas) adalah 0,024 ppm, perlakuan B (80\% ekstrak kulit nanas adalah 0,029 ppm, perlakuan C (60\% ekstrak kulit nanas) adalah 0,009 ppm, dan perlakuan D (40\% ekstrak kulit nanas) adalah 0,444 ppm.

Nugget merupakan salah satu jenis makanan hasil olahan dari daging dan dapat bertahan dalam jangka waktu yang cukup lama di dalam freezer.Waktu maksimal nugget tanpa menggunakan bahan pengawet dalam lemari pendingin adalah $\pm 2-3$ minggu.Pembuatan nugget pada umumnya menggunakan daging sapi atau daging ayam, masih jarang dijumpai pembuatan nugget dengan menggunakan daging ikan.Hal ini 
disebabkan karena informasi pembuatan nugget dengan bahan dasar ikan masih kurang. Nugget yang berbahan dasar daging ikan, biasa diistilahkan dengan fish nugget, dan umumnya ikan yang digunakan sebagai bahan dasar pembuatan fish nugget adalah ikan tenggiri.

Salah satu inovasi yang dapat dilakukan adalah dengan mengolah limbah ikan berupa jeroan, kulit, ataupun sisa daging pada bagian kepala ikan menjadi bahan dasar dalam pembuatan fish nugget.Menurut Rusmana dkk, bahwa Limbah yang dihasilkan dari kegiatan perikanan masih cukup tinggi, yaitu sekitar 20-30 persen. Produksi ikan yang telah mencapai 6.5 juta ton pertahun akan menghasilkan sekitar 2 juta ton terbuang sebagai limbah (Rusmana, 2006). Tingginya produksi limbah ikan yang dihasilkan seiap tahun merupakan peluang besar dalam mengolah limbah ikan menjadi produk yang bernilai jual tinggi. Limbah ikan seperti: jeroan, kulit, dan kepala ikan masih mengandung senyawa kompleks yang dibutuhkan oleh tubuh seperti protein sehingga masih sangat memungkinkan untuk diolah menjadi aneka makanan olahan dengan nilai gizi tinggi. Selain mengolah secara langsung, limbah ikan dapat diberi perlakuan sebelum di olah menjadi produk makanan, seperti dengan perendaman atau perendaman ekstrak kulit nanas.

Kulit nanas mengandung protease yang disebut dengan bromelin, hal ini sejalan dengan pendapa Murniai yang menyatakan bahwa buah nanas yang masih hijau atau belum matang ternyata mengandung bromelin lebih sedikit dibanding buah nanas segar yang sudah matang. Penelitian yang lain menunjukkan buah yang matang karena diperam memiliki kandungan yang lebih sedikit dibandingkan buah yang masih hijau. Buah nanas mengandung enzim bromelin, enzim tersebut terdapat pada hati, kulit, dan tangkai nanas.Kandungan enzim bromelin pada bagian-bagian buah bervariasi dan pada kulit buah \pm 0,050-0,075\%.Penggunaan bromelin sebagai protease diharapkan mampu meningkatkan nilai cerna dari fish nugget berbahan dasar limbah ikan, sehingga produk yang dihasilkan memiliki keunggulan dibandingkan dengan produk yang sudah ada sebelumnya.

Kulit nanas dipotong kecil dan dicuci bersih serta dihaluskan dengan menggunakan blender.Untuk mendaptkan ekstrak yang diasumsikan 100\%, maka $100 \mathrm{~g}$ kulit nanas dicampur dengan air sebanyak $100 \mathrm{ml}$ lalu disaring. Limbah ikan yang telah dibersihkab dan dipisahkan berdasarkan jenisnya, selanjutnya direndam dengan larutan ekstrak pada konsetrasi yang telah dibat yaitu: 100\%, 80\%, 60\%, dan 40\%. Lama waktu perendaman adalah 30 menit yang bertujuan untuk meningkatkan nila cerna produk olahan dan berfungsi untuk menghilangkan bau amis dari limbah ikan. Bumbu yang telah disiapkan di haluskan dan dicampurkan ke dalam adonan ikan yang telah halus lalu kemudian ditambahkan dengan tepung tapioca dan dikukus selama 20 menit.Bentukan fish nugget yang telah jadi selanjutnya diberi tepung roti dan digoreng atau bisa disimpan 
di di dalam freezer sampai waktunya untuk diolah menjadi aneka hidangan dengan kandungan protein yang cukup tinggi.

Protein merupakan senyawa organik yang sebagian besar unsurnya terdiri dari Karbon, Hidrogen, Oksigen, Nitrogen, Sulfur dan Fosfor. Ciri khusus protein adalah adanya kandungan Nitrogen. Berdasarkan bentuknya, protein dapat diklasifikasikan dalam tiga bagian, yaitu: protein berbentuk bulat, serat dan gabungan keduanya.Protein berbentuk bulat (globular), diantaranya adalah: (1) albumin adalah protein yang larut dalam air dan menggumpal apabila terkena panas. Umumnya albumin menjadi komponen pada albumin telur, albumin serum, leucosin pada gandum dan legumelin pada kacangkacangan; (2) globulin umumnya tidak larut dalam air tetapi larut dalam asam kuat dan menggumpal apabila terkena panas. Globulin terdapat sebagai komponen globulin serum, fibrinogen, myosinogen, edestin pada biji hemp, legumin pada kacang-kacangan, concanavalin pada jack bean dan excelsin pada kacang Brazil. (3) glutelin tidak larut dalam air dan pelarut netral, tetapi lebih cepat larut dalam larutan asam atau basa.

Fungsi protein meliputi: (1) struktur penting untuk jaringan urat daging, tenunan pengikat, kolagen, rambut, bulu, kuku dan bagian tanduk serta paruh, (2) sebagai komponen protein darah, albumin dan globulin yang dapat membantu mempertahankan sifat homeostatis dan mengatur tekanan osmosis, (3) terlibat dalam proses pembekuan darah sebagai komponen fibrinogen, tromboplastin, (4) membawa oksigen ke sel dalam bentuk sebagai hemoglobin, (5) Sebagai komponen lipoprotein yang berfungsi mentransportasi vitamin yang larut dalam lemak dan metabolit lemak yang lain, (6) sebagai komponen enzim yang bertugas mempercepat reaksi kimia dalam sistem metabolisme dan (7) sebagai nukleoprotein, glikoprotein dan vitellin.

Mengingat pentingnya protein di dalam tubuh, maka dalam penelitian ini dilakukan inovasi dalam meningkatkan nilai cerna produk olahan limbah ikan yaitu memberi perlakuan pada limbah ikan berupa perendaman dengan ekstrak kulit nanas yang mengandung bromelin. Hasil pengujian menunjukkan bahwa kadar protein (kadar NTotal) pada fish nugget berbeda pada tiap perlakuan dengan kadar protein tertinggi diperoleh pada perendaman ekstrak kulit nanas konsetrasi $40 \%$. Salah satu faktor yang mempengaruhi kerja enzim adalah konsetrasi enzim dan substrat, dimana enzim memiliki kecepatan dalam bekerja pada konsetrasi tertentu, demikian pula dengan jumlah substrat turut mempengaruhi kerja enzim. Hasil penelitian ini memberikan informasi bahwa konsetrasi ekstrak kulit nanas 40\% lebih baik dalam meningkatkan kadar protein fish nugget berbahan dasar limbah ikan bila dibandingkan dengan konsetrasi lainnya.

\section{KESIMPULAN}

1. Pembuatan fish nugget dari limbah ikan cukup mudah dan sederhana yaitu hanya menggunakan bagian jeroan, kulit, dan sisa daging pada baian kepala ikan kemudian direndam dengan ekstrak kulit nanas dan dibuat dalam adonan serta ditambahkan 
dengan bumbu, selanjutnya dikukus selama 15 menit sampai fish nugget matang dan siap untuk diolah menjadi aneka hidangan

2. Perlakuan konstentrasi ekstrak kulit nanas terhadap kadar protein fish nugget memberikan hasil yang berbeda. Konserasi $40 \%$ memberikan hasil yang terbaik bila dibandingkan dengan konsetrasi 100\%, 80\%, dan 60\%.

\section{SARAN}

Perlu adanya sosialisasi kepada masyarakat tentang cara pembuatan fish nugget berbahan dasar limbah ikan dan perlu adanya kajian lebih mendalam tentang daya tahan produk berdasarkan lama penyimpanan dengan berpedoman kepada ALT Bakteri dan Jamur

\section{DAFTAR PUSTAKA}

Afrianto, E. dan Evi Liviawati. 1991. Pengawetan dan Pengolahan Ikan. Kanisius. Yogyakarta.

Anonim.2000. Petunjuk Praktikum Biokimia Untuk PSIK (B) Fakultas Kedokteran Universitas Gadjah Mada.Lab. Biokimia FK UGM. Yogyakarta

Burgess, G.H.O., C.L. Cutting, J.A. Lovern dan J.J. Waterman. 1965. Fish Handling and Processing. Her majesty's Stationary Office. Edinburg.

Fardiaz, S. 1993. Mikrobiologi Pangan I. PT. Gramedia Pustaka Utama. Jakarta

Guyton AC, Hall JE. 1996. Buku Ajar Fisiologi Kedokteran, Edisi IX, Penerjemah: Setiawan I, Tengadi LMAKA, Santoso A. EGC. Jakarta.

Junianto, Haetami dan Maulina.2006. Produksi Gelatin Dari Tulang Ikan Dan Pemanfaatannya Sebagai Bahan Dasar Pembuatan Cangkang Kapsul.http://pustaka.unpad.ac.id/wpcontent/produksi_gelatin_dari_tulang_ika $n . p d f$

Murniyati AS dan Sunarman. 2000. Pendinginan, Pembekuan dan Pengawetan Ikan. Kanisius. Yogyakarta.

Murray RK, Granner DK, Mayes PA, Rodwell VW. 2003. Biokimia Harper, Edisi XXV, Penerjemah Hartono Andry. EGC. Jakarta.

Nitibaskara, R. 1981. Laporan Studi Pengembangan Industri Kecil Pengolahan Ikan. Laporan Fakultas Perikanan IPB. Bogor.

Rombaut, R. 2005. Dairy Microbiology and Starter Cultures.Laboratory of Food Technology and Engineering.Gent University. Belgium

Rusmana, Deny dan Abun.2006. Evaluasi Nilai Kecernaan Limbah Ikan Tuna (Thunnusatlanticus) Produk Pengolahan Kimiawi Dan Biologi Serta Nilai Retensi Nitrogen Pada Ayam

Broiler.http://pustaka.unpad.ac.id/wpcontent/uploads/2009/10.pdf. 
Soekarto, S.T. 1990. Dasar-dasar Pengawasan dan Standarisasi Mutu Pangan.IPB Press. Bogor.

Stryer L. 1996. Biokimia. Edisi IV, Penerjemah: Sadikin dkk (Tim Penerjemah Bagian Biokimia FKUI). EGC. Jakarta.

Supardan. 1989. Metabolisme Protein. Lab. Biokimia Universitas Brawijaya. Malang.

Trilaksani, W, Salamah, E., Nabil, M. 2006. Pemanfaatan Limbah Tulang Ikan Tuna (Thunnus spp.) sebagai Sumber Kalsium dengan Metode Hidrolisis Protein.BuletinTeknologi Hasil Perikanan Vol IX Nomor 2 Tahun 2006

Wong, DWS. 1989. Mechanism and Theory in Food Chemistry. Academic Press. NY

Zaitsev, V., I. Kizevetter, L. Lagunov, T. Makarova, L. Munder dan V. Podsevalow.1969 Fish Curing and Processing. Terjemahan A. De Marindol. M.R. Publisher. Moskow

Buckle, K. A., dkk.. 2000. Ilmu Pangan. Diterjemahkan oleh Adiono dan Hari Purnomo., UI Press. Jakarta.

Djidje, M.N., Sartini. 2008. Analis Mikrobiologi Farmasi. Laboratorium Mikrobiologi Farmasi, Jurusan Farmasi, F. MIPA, UNHAs. Makassar.

Djide, M. N. Sartini. 2005. Dasar-Dasar Mikrobiologi. Universitas Hasanuddin, Makassar.

Dwyana, Zaraswati, 2004. Analisis Mikrobiologi Bahan Pangan. Universitas Hasanuddin, Makassar.

Koes, Irianto. 2006. Mikrobiologi Jilid 2. Yasama Widya. Bandung. 